\title{
CYSTICERCOSIS IN EPILEPTIC PATIENTS OF MULUNGU DO MORRO NORTHEASTERN BRAZIL
}

\author{
IRENIO GOMES*, MARIELZA VEIGA*, DOLORES CORREA**, ANTONIO MEZA-LUCAS**, \\ OLGA MATA **, ROBERTO CARLOS GARCIA**, ALEJANDRO OSORNIO**, \\ ROSÂNGELA RABELO***, RITA LUCENA*, AILTON MELO*
}

\begin{abstract}
With the aim to study the magnitude of infection by the metacestode of Taenia solium in a population of epileptic patients in the arid region of Bahia, Northeastern Brazil, we examined 200 consecutive cases who attended an ambulatory clinic in the disctrict of Mulungu do Morro. Sixty-six of the patients had a diagnosis of epilepsy. From them $10(15.2 \%)$ presented antibodies against a specific fraction of antigens in Western blot, and 4 $(6.0 \%)$ had circulating parasite products, as tested by capture ELISA. Only 1 case was positive for antibodies and antigens. We found that the frequency of seropositivity was related to the time without epileptic seizure. We conclude that cysticercosis is endemic in the region of Mulungu do Morro and that it is related to a benign form of epilepsy.
\end{abstract}

KEY WORDS: cysticercosis, epilepsy, seizures, neurocysticercosis, epidemiology.

\section{Cisticercose em pacientes epilépticos de Mulungu do Morro - Bahia, Brasil}

RESUMO - Com o objetivo de estudar a magnitude da infecção por cisticercose em uma população de indivíduos epilépticos de uma cidade do sertão da Bahia, nordeste do Brasil, examinamos 200 pacientes consecutivos que procuraram o ambulatório de neurologia da Universidade Federal da Bahia no Município de Mulungu do Morro. Do total de casos, 66 tiveram o diagnóstico de epilepsia caracterizado por duas crises com mais de 48 horas de intervalo entre elas. Entre os pacientes epilépticos, $10(15,2 \%)$ apresentaram anticorpos contra uma fração específica de antígenos pelo método de Western blot e em 4 (6\%) antígenos do parasita foram detectados através do método ELISA. Apenas um caso foi positivo para antígenos e anticorpos. Observamos que a frequência de cisticercose foi maior entre os indivíduos com menos que uma crise por ano e naqueles com epilepsia controlada. Concluimos que a região de Mulungu do Morro tem alta endemicidade para cisticercose e os nossos dados sugerem que a epilepsia decorrente dessa infecção apresenta tendência à benignidade.

PALAVRAS-CHAVES: cisticercose, epilepsia, neurocisticercose, epidemiologia.

Neurocysticercosis caused by the Taenia solium metacestode is the most frequent parasitic neurologic disease in the world ${ }^{1}$. It is mostly characterized by seizures mainly in young adults. Several studies have established the importance of cysticercosis as one of the most important risk factors for seizures in Brazil ${ }^{2-4}$. Meanwhile, the majority of these studies constitute the reality of public hospitals but they do not define the epidemiological reality of an open population.

In April 1998, the Division of Neuroinfectology and Neuroepidemiology of the Neuropsychiatry Department of Federal University of Bahia in cooperation with the Health Secretary of the State of Bahia initiated a program to define the impact of the taeniosis/cysticercosis complex (TCC) in the state.

Government data of the state of Bahia showed that Mulungu do Morro, a small city in the state, was one of the main consuming anti-epileptic drugs (AED) regions. These data suggested that

*Universidade Federal da Bahia, Brasil **Instituto Nacional de Diagnóstico y Referencia Epidemiologicos, Mexico; ***Secretaria da Saúde do Estado da Bahia, Brasil. Irenio Gomes e Rita Lucena são bolsistas de doutorado do CNPq e Ailton Melo é bolsista pós-doutorado do CNPq. Apoio: CADCT-SEPLANTEC-BAHIA/BRASIL. Aceite: 5-abril-2000. 
Table 1. Prevalence of positive serology for cysticercosis and epidemiological characteristics of 66 epileptic patients from Mulungu do Morro, Bahia, Brazil.

\begin{tabular}{|c|c|c|}
\hline Variable & Number of patients (\%) & Prevalence \% \\
\hline \multicolumn{3}{|l|}{ Gender } \\
\hline Males & $34(51.5)$ & 11.8 \\
\hline Females & $32(48.5)$ & 18.8 \\
\hline \multicolumn{3}{|l|}{ Age (years) } \\
\hline$<=10$ & $10(15.2)$ & 10.0 \\
\hline $11-30$ & $34(51.5)$ & 14.7 \\
\hline $31-50$ & $17(25.8)$ & 17.6 \\
\hline$>=51$ & $5(7.6)$ & 20.0 \\
\hline \multicolumn{3}{|c|}{ Scholarity (years) } \\
\hline$<4$ & $51(78.5)$ & 17.6 \\
\hline$>=4$ & $14(21.5)$ & 7.1 \\
\hline \multicolumn{3}{|c|}{ No. of persons per house } \\
\hline$<5$ & $38(58.5)$ & 21.1 \\
\hline$>=5$ & $27(41.55)$ & 7.4 \\
\hline \multicolumn{3}{|l|}{ Pig breeding } \\
\hline Yes & $25(37.9)$ & 12.0 \\
\hline No & $41(62.1)$ & 17.1 \\
\hline \multicolumn{3}{|c|}{ Pork meat ingestion } \\
\hline Yes & $53(80.3)$ & 17.0 \\
\hline No & $13(19.7)$ & 7.7 \\
\hline \multicolumn{3}{|c|}{ Insufficiently cooked pork meat ingestion } \\
\hline Yes & $16(27.1)$ & 18.8 \\
\hline No & $43(72.9)$ & 11.6 \\
\hline \multicolumn{3}{|c|}{ Raw vegetables ingestion } \\
\hline Yes & $62(93.9)$ & 16.1 \\
\hline No & $4(6.1)$ & 0.0 \\
\hline
\end{tabular}

it could be endemic for neurocysticercosis; thus, we began this study with the aim to determine the prevalence of cysticercosis among epileptic patients and to describe the epidemiological and clinical characteristics of them.

\section{METHOD}

The city of Mulungu do Morro is located in a poor region of the west of Bahia, distant $460 \mathrm{~km}$ from Salvador, the capital city of the state, and it has an estimated population of 15000 inhabitants and a surface of $515 \mathrm{~km}^{2}$. Its economy is mainly based in the culture of beans, coffee, mamona, sisal and corn.

After contact with the authorities and local leaders, we initiated a serological survey in epileptic patients that arrived to the ambulatory of neurology clinics created $a d$ hoc for the project. They were recruited between April and May 1998. Patients were assisted by certified neurologists of the Neurology Service-Federal University of Bahia. During the medical assistance clinical and epidemiological files were fulfilled and blood samples were collected for further analysis. 
Table 2. Prevalence of serum antibodies for cysticercosis and clinical characteristics of 66 patients from Mulungu do Morro, Bahia, Brazil.

\begin{tabular}{lcc}
\hline Variable & Number of patients (\%) & Prevalence $\%$ \\
\hline Seizures types & $29(43.9)$ & \\
$\quad$ Tonic-clonic seizures & $6(9.1)$ & 13.8 \\
$\quad$ Simple and complex partial seizures & $23(34.8)$ & 16.7 \\
Partial with secondary generalization & $8(12.1)$ & 13.0 \\
Others & & 25.0 \\
Frequency of seizures & $24(36.4)$ & 12.5 \\
$\quad$ More than 1 for week & $30(45.5)$ & 13.3 \\
Between 1 for week and 1 for year & $12(18.2)$ & 25.0 \\
Less than 1 for year & & 8.0 \\
Last seizure* & $50(76.9)$ & 36.4 \\
$<6 \mathrm{~m}$ & $11(16.9)$ & 50.0 \\
$\geq 6 \mathrm{~m}$ and $\leq 2 \mathrm{y}$ & $4(6.2)$ & \\
$>2 \mathrm{y}$ & &
\end{tabular}

Antibodies against T. solium metacestode were identified by the enzyme-linked immunoelectrotransfer blot (EITB) assay as described by Tsang et al. ${ }^{5}$. This assay uses lentil-lectin purified glycoprotein antigens (diagnostic bands gp50, gp39-42, gp24, gp21, gp18, gp14 and gp13) in an immunoblot format to detect infectionspecific antibodies. Positive reaction to at least 1 band is considered positive. Parasite antigens were also searched by a capture ELISA according to a previously described method ${ }^{6}$.

Collected data were inserted in a data bank (Access, version 7.0) and analyzed with the help of a statistical package (SPSS version 7.0). Either chi square or Fischer exact tests were used to analyze associations between clinical or epidemiological variables and serological results.

\section{RESULTS}

Two hundred patients attended the clinics. From them 66 had epilepsy characterized by at least two seizures with more than 48 hours intervals. The rate of positive antibody test in this group was $15.2 \%$, while only $4(6.1 \%)$ were found to be positive for antigens. One case was positive in both tests.

Table 1 presents the prevalence of antibodies and some clinical and demographic characteristics of the studied patients. Besides we found a greater prevalence in some groups like females or adults, we did not find statistical significance of these differences. We should emphasize eventhough, that more than $16 \%$ of the people who ate raw vegetables presented antibodies. In the other way it was not found antibodies in the group of persons who did not eat raw vegetables.

Regarding the clinical aspects, we found a statistical relation between the seropositivity and the time elapsed from the last seizures episode $(\mathrm{p}<0.05$; Table 2$)$.

\section{DISCUSSION}

Cysticercosis has been a great concern of neurologists in Latin America for several decades and many papers have described clinical, epidemiological and immunological characteristics of this parasitosis $^{7-9}$. In Brazil, the majority of studies about cysticercosis have been done in the South and Southeast regions and the knowledge of cysticercosis in Northeastern region has only been related 


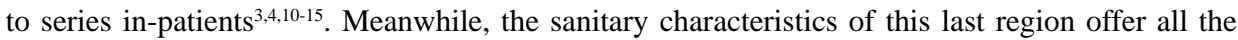
opportunities for the development of the TCC. This study points to the existence of a highly endemic area for TCC in the state of Bahia.

The choice of a city with increased consumption of AED was established because epilepsy is the main clinical manifestation of cysticercosis ${ }^{1}$. Our results suggest that high consumption of AED in a small city within underdeveloped regions could be utilized as a pointer to epidemiologic studies in the field of cysticercosis.

In this research we utilized the glycoprotein based EITB as diagnostic criteria to determine the prevalence of cysticercosis. This has not been used before in Brazil, and it has been suggested to be more accurate to support population studies ${ }^{16}$. The prevalence found in Mulungu do Morro is similar to the one in rural areas of other countries of Latin America ${ }^{17}$. Thus, it reinforces the suggestion that the community we studied is under the infective pressure of this parasite.

The low frequency of cases with circulating antigens could be due to the presence of antibodies in the same samples, which are probably competing with the antigen-capture assay. Three cases were found to have only antigen; these are probably persons recently infected, since they had not mounted an antibody response yet. By summing both antigen and antibody positive cases, a prevalence of $19.7 \%$ of persons in contact with the parasite is suggested in the present study.

Our study points to a more benign evolution of epilepsy in patients with cysticercosis than among cases with other etiologies, but even with this apparently benign evolution this disease is responsible for job absence and risk for accidents because this is a predominantly farm population. Thus, it is necessary to implement measures to control/eradicate the TCC in Brazil.

\section{REFERENCES}

1. Davis LE, Kernfeld M. Neurocysticercosis: neurologic, pathogenic, diagnostic and therapeutic aspects. Eur Neurol 1991;5:229-240.

2. Takayanagui OM. Neurocysticercosis: I. Clinical and laboratory course of 151 cases. Arq Neuropsiquiatr 1990;48:1-10

3. Arruda WO. Etiology of epilepsy: a prospective study of 210 cases. Arq Neuropsiquiatr 1991;49(3):251-254

4. Agapejev S. Epidemiology of neurocysticercosis in Brazil. Rev Inst Med Trop São Paulo 1996; 38(3):207-216.

5. Tsang VCW, Brand JA, Boyer AE. An enzyme-linked immunoelectrotransfer blot assay and glycoprotein antigens for diagnosing human cysticercosis. J Infect Dis 1989;159:50-59.

6. Aranda-Alvarez JG, Tapia Romero R, Alcántara-Anguiano Y, et al. Human cysticercosis: risk factors associated with seric antigens in an open community of San Luis Potosí, México. Ann Trop Med Parasitol 1995; 89:689-692.

7. Garcia HH, Gilman RH, Tsang VC, Gonzalez AE. Clinical significance of neurocysticercosis in endemic village. The Cysticercosis Working Group in Peru. Trans R Soc Trop Med Hyg 1997;91:176-178.

8. Medina MT, Rosas E, Rubio-Donnadieu F, Sotelo J. Neurocysticercosis as the main cause of late-onset epilepsy in Mexico. Arch Intern Med 1990;150:325-327.

9. Spina-França A, Livramento JA, Bacheschi LA, Garcia-Lopes P. Cerebrospinal fluid immunoglobulins in cysticercosis of the central nervous system. Arq Neuropsiquiatr 1976;34:40-45.

10. Machado AB, Pialarissi CS, Vaz AJ. Human cysticercosis diagnosed at a general hospital, São Paulo SP. Rev Saude Publica 1988;22:240-244.

11. Gonçalves-Coelho TD, Coelho MD. Cerebral cysticercosis in Campina Grande, Paraíba- northern Brazil: computerized tomography diagnosis importance. Arq Neuropsiquiatr 1996;54:94-97.

12. Sousa AQ, Sa HL, Queiroz TR, Horta WG, Pearson RD. Neurocysticercosis in Ceara State, northeastern Brazil: a review of 119 cases. Am J Trop Med Hyg 1998;58:759-762.

13. Takayanagui OM, Jardim E. Clinical aspects of neurocysticercosis: analysis of 500 cases. Arq Neuropsiquiatr 1983;41:50-63.

14. De Albuquerque ES, Galhardo I. Neurocysticercosis in the State of Rio Grande do Norte: report of 8 cases. Arq Neuropsiquiatr 1995;53:464-470.

15. Trevisol-Bittencourt PC, da Silva NC, Figueredo R. Prevalence of neurocysticercosis among epileptic in-patients in the west of Santa Catarina, southern Brazil. Arq Neuropsiquiatr 1998;56:53-58.

16. Garcia HH, Martinez M, Gilman R, et al. Diagnosis of cysticercosis in endemic regions. Lancet 1991;338:549-551.

17. Schantz PM, Sarti E, Plancarte A, Wilson M, Criales JL, Flisser A. Community-based epidemiological investigations of cysticercosis due to Taenia solium: comparison of serological screening tests and clinical findings in two populations in Mexico. Clin Inf Dis 1994;18:879-895. 